\title{
Harry Hansen's Literary Career
}

\author{
W I L L I A M R O B A
}

In 1954 Ben Hecht described Iowa-born Harry Hansen as a quiet book lover who "lived among books like a pilgrim in a rain of manna." 1 This is an appropriate description, for Hansen's literary criticism appeared primarily in newspapers. His career during a unique period of American book publishing, from 1915 until 1945 . was recorded in thousands of daily columns. ${ }^{2}$ Hansen's writings combined an admiration for European writers with an abiding appreciation of Middle West regional writing.

Since he was literary editor of the Chicago Daily News, the name of Harry Hansen (1884-1977) appears in many books describing the Chicago writers of the early twentieth century. But there has been no analysis of his role in the "Chicago literary renaissance" of the 1920s. Furthermore, no extended discussion of his career has been published since 1929.3 Hansen's career conveniently falls into three distinct periods. The first is his boyhood in Davenport, Iowa; the second covers his years in Chicago; and the third relates to his residence in suburban New York City.

\section{I}

Harry Hansen participated in a great national drama of the nineteenth century: the assimilation of European life into American society. Hansen was a first-generation American who grew up in Davenport, Iowa, while acquiring an identity quite different from his parents. In Davenport, the process of learning the values, beliefs,

1 A Child of the Century (New York: Simon and Schuster, 1954), p. 341.

2 John Tebbel, A History of Book Publishing in the United States (New York: R. R. Bowker Company, 1978), 3: 5-7.

3 C. Hartley Grattan, "Harry Hansen of the World," Brentano's Book Chat 8, no. 6 (November-December 1929): 33-37. 
and behavior of Americans exemplified Theodore Roosevelt's assertion that "the old American stock . . . has absorbed the immigrants and remained nearly unchanged." 4 The process of assimilation influenced Hansen's outlook, shaping his eventual choice of a literary career.

Harry Hansen's father arrived in Davenport in the 1860 s, proud of his Danish heritage but eager to succeed in business. In Davenport this meant selling goods to German farmers, who were the largest ethnic group to settle in eastern Iowa. Hans Hansen identified with the German community and his wagon-making business prospered. He was remembered by his son as someone who "built wagons to last a lifetime, for the theory that replacement creates sales had not yet become current in America."5 Hans joined German organizations in the city as part of his new identity. He sang faithfully with the Germania Mannerchor, a group of Lutheran singers composed of prominent businessmen, including the grocer Carl Biederbeck, that furnished entertainment for social events. When the elder Hansen retired from business in 1890, he had achieved the economic dream of success shared by millions of other immigrants.

Harry Hansen's mother came from the same part of Europe as her husband, the German province of Holstein, which was adjacent to Denmark. Christine Jochims and her parents moved to Davenport in 1871 as part of a larger migration. She married Hans Hansen in the summer of 1883 at the relatively late age of 32 . Harry, their only child, was born at home on December 26, 1884. She shared her husband's interest in music and attended concerts of the Mannerchor to hear her husband sing. She enjoyed the popular programs at the Turner Grand Opera House, taking Harry with her when he was young. ${ }^{6}$

In the collegiate atmosphere of Davenport High School, Harry Hansen started writing. He wrote two short stories that were published in Red and Blue, a monthly magazine edited by students. "The Last Cruise of the Buena Vista" and a serial, "Told in the Twilight," described the adventures of sailors in exotic locations. Their only value is to indicate Hansen's lifelong interest in sea stories. ${ }^{7}$ They were selected by the literary editor of the magazine, Arthur

4 Theodore Roosevelt to James Bryce, January 6, 1888, The Letters of Theodore Roosevelt, ed. Elting E. Morrison (Cambridge: Harvard University Press, 1951), p. 134.

5 Harry Hansen, "A Davenport Boyhood," Palimpsest 37, no. 4 (April 1956): 163-64.

6 Ibid., p. 178. 
Davison Ficke, who maintained a certain standard of excellence in the school magazine. He was the son of a former mayor, C. A. Ficke. As president of the Adelphian Society, Ficke acted as a model of social acceptability for the aspiring writer, Harry Hansen.

Hansen persisted and tried his hand at nonfiction writing. In 1901 the Daughters of the American Revolution offered a prize of $\$ 5$ for the best essay on the topic, "The History of Davenport Prior to 1860." This organization represented the Davenport elite at their finest, and Alice French personally judged the essay contest. A newspaper account described the prize as a great honor: "the thought of winning a prize for literary achievement from this noted writer Alice French has spurred on those in the contest." ${ }^{8}$ Hansen was selected by Miss French as the prize winner. Public recognition by the New England elite was a major accomplishment for Harry Hansen. Publicly, the newspaper described how "all essays submitted to the historical committee were excellent, but the choice was given to the one submitted by Hansen, as it was easily the best." 9

The newspaper also influenced the direction of Harry Hansen's interest in writing. He started working for the Republican as a "telegraph man" the day after he graduated from high school in January 1903. This was the job of selecting national news for republication from the wire service. Within half a year, Hansen got a better job at the Times as a "cub" reporter. ${ }^{10}$ The managing editor liked his work during the first year and rewarded him with a special assignment: to cover the Republican convention in Chicago. This was Hansen's first trip to a big city where famous reporters were covering the nomination of Theodore Roosevelt, and the beginning of a half-century career in journalism for Hansen. While working there, Hansen became friends with another reporter, Floyd Dell. Dell had dropped out of school and was secretly writing poetry while working for the Times. Hansen accepted the journalistic assumptions of the editors: neutrality in covering accidents, death, and suffering, but partisan support of certain politicians and the city's elite.

By 1905 Harry Hansen had taken up residence in a city whose writers were receiving national recognition. His contemporary, Arthur Davison Ficke, had had several volumes of poetry published. An older writer from Davenport, Susan Glaspell, had returned from

7 Red and Blue 2, no. 1 (September 1899): 6-7; 2, no. 3 (November 1899): 5-7; 2, no. 4 (December 1899): 7-8. Copies in Iowa State Historical Society.

8 "Week at School," Davenport Times, May 4, 1901, p. 4.

9 "Colonial Dames," Davenport Times, June 1, 1901, p. 4.

10 "Davenport Boyhood," p. 222. 
a year of graduate work at the University of Chicago with a short story published in a national magazine. After two years of newspaper work, Hansen decided to become a college student. He had taken an adult education course through the local Unitarian church but wanted to follow the footsteps of Ficke, who had graduated from Harvard, and Glaspell, who had graduated from Drake University in Des Moines.

From 1905 until 1926, like thousands of other midwestern boys who moved to the big city, Hansen became a transplanted Chicagoan. Unlike Floyd Dell, who stayed in Chicago only five years, Hansen's stay was long enough to influence his career in writing. Before taking the position of literary editor for the Chicago Daily News, he had trained as a reporter, learned the techniques of publicity, and had become a skilled foreign news analyst. Hansen was one of several first-generation Americans who chose journalism for a career. His editorial position enabled him to describe newsworthy literary events in his weekly column.

Hansen became a freshman at the University of Chicago in September 1905, after more than two years of newspaper work. Other Davenporters had matriculated at the university, enjoying the campus which had been built on the site of the 1893 world's fair. Three landmarks were still standing in 1905: the Del Prado Hotel, the German Building, and the Fine Arts Building (later transformed into the first Museum of Science and Industry). 11 In strolling along the university campus, Hansen walked along a tree-lined boulevard that replaced the hurly-burly of the fair's Midway Plaisance, touching the temporary structures near the subway stop at Stony Island that remained as artist studios. ${ }^{12}$ Nearby were the new houses of fashionable Hyde Park and the green space of Washington Park.

Hansen used his university experience to launch a career in writing. After studying English at the University of Chicago, he was chosen as a senior to coedit the new alumni magazine. The University of Chicago Magazine was a monthly publication that incorporated earlier university magazines into a periodical with broad appeal. It was an attempt to copy the success of Harvard and other

11 Harry Hansen. "The Miracle in Jackson Park and What It Achieved," Illinois '68, Supplement to the Chicago Tribune, July 4. 1968, p. 29.

12 Harold M. Mayer and Richard C. Wade, Chicago: Growth of a Metropolis (Chicago: University of Chicago Press, 1969), pp. 200-11. 
"Ivy League" university magazines that offered articles of interest to nongraduates in addition to alumni news. After graduating from the university in 1909, Hansen became sole editor of the magazine and continued to publish faculty-written articles of scholarly interest. He also coordinated alumni activities with monthly news items. This magazine offered Hansen his first opportunity to review books, although it is now difficult to determine which reviews were written by Hansen because they are unsigned.

Hansen changed his work responsibilities in 1911 by becoming the public relations representative for the University of Chicago. He had his own office in the university's Press Building where he met reporters every day with press releases and news conferences. As a manipulator of words in a relatively new profession. Hansen was able to enrich his university milieu through contacts with newspaper friends such as Burton Rascoe and Henry Blackman Sell, who had been students with Hansen. He also gained experience in dealing with newspaper editors, such as Henry Justin Smith, who had graduated from the university in 1898 .

In 1913 Hansen rearranged his career objectives by going back into newspaper work. He had valuable experience from the two years he worked as a reporter in Davenport, an academic degree, and experience in editing an alumni magazine. He was hired by the news editor of the Daily News, Henry Justin Smith. He first went to work in the real estate department of the newspaper, helping to produce a special section for the midweek edition. ${ }^{13} \mathrm{He}$ successfully applied his public relations experience to the assignment before becoming a news reporter again.

Hansen's career as a Daily News reporter took a major shift in 1914. Shortly after his marriage in April, he was chosen to head the Berlin office of the Daily News' European news service. He and his wife sailed to France in July and after several weeks in Paris, moved to Berlin. ${ }^{14}$ In early August, Hansen went to Belgium before the advance of the German Imperial Army. He and three other foreign correspondents were arrested and held in Beaumont, the headquarters of a German army section. ${ }^{15}$ Hansen was the only American

13 Letter of Henry Justin Smith to Harry Hansen. October 17, 1914, Hansen Papers, Newberry Library.

14 Letter of Ruth McLernon Hansen, December 9, 1977, The University of Iowa Libraries.

15 Charles H. Dennis, Victor Lawson; His Time and His Work (Chicago: University of Chicago Press, 1935), p. 274. Hansen later wrote an essay about Beaumont, a town of around one thousand people. He suggested a sense of military cycles with the town having experienced the Napoleonic Wars a century 
who understood German and the strategic buildup of the German army as it prepared for the first decisive engagement of the warthe Battle of the Marne (September 5-9). After escaping with the others, Hansen sent reports to the London office of the Daily News for recabling to Chicago. His exclusive coverage enhanced his reputation as a foreign correspondent. ${ }^{16}$

During the next two years Hansen went on special assignment to Rome, Venice, Vienna, Norway, Sweden, and the Baltic area as he reported the war for the Chicago Daily News and its syndicated coverage. The newspaper arranged with the Northcliffe press syndicate in England for reciprocal news services in 1915, the only real competition to the New York newspapers, which "practically monopolized the business of serving as middleman for other daily newspapers in the United States."17 Hansen had assumed editorial control over other foreign correspondents of the Daily News and seriously considered a career as a foreign news analyst. He finally decided that his family responsibilities required a secure home in America (his first daughter had been born in November 1915).18 He bought a home in Winnetka, a northern suburb of Chicago, in 1916, and commuted to work every day by train.

By the end of World War I, Hansen had developed a reputation for translation. In 1917 the literary editor of the Daily News, Henry Blackman Sell, who had been a classmate at the University of Chicago, started assigning him foreign language books to review. Hansen also translated A Peace Congress of Intrigue (1918), adding notes and an introduction to a compilation of primary documents prepared by Friedrich Freksa. Immersion in these diplomatic dispatches prepared Hansen for yet another European assignment. In 1919 he cov-

before. "What Happened in Beaumont," University of Chicago Magazine 8, no. 5 (March 1916): 207.

16 Philip Knightly, The First Casualty (New York: Harcourt, 1975), p. 116. Hansen covered the German occupation of Belgium as a participant-observer. He personally witnessed no atrocities as reported by the British War Ministry Office, primarily for American newspaper reprinting. Instead, Hansen found the German Imperial Army to be professionally disciplined. Hansen refused to cooperate with the censors of the Allied Forces and joined in April 1915 with Roger Lewis of the Associated Press, Irwin Cobb of the Saturday Evening Post, James O'Donnell Bennett, and John T. McCutcheon of the Chicago Tribune in signing a declaration rejecting the alleged civilian atrocities. The complete text appears in Arthur Ponsonby, Falsehood in Wartime (London: George Allen and Unwin, 1928), p. 130.

17 Ralph O. Nafziger, "World Correspondents and Censorship of the Belligerents," Journalism Quarterly 14, no. 3 (September 1937): 238.

18 Letter of Ruth McLernon Hansen, December 11, 1977, The University of Iowa Libraries. 
ered the Versailles Peace Conference, specializing in feature stories syndicated by the North American Newspaper Alliance (NANA). These were collected into his first book, The Adventures of the Fourteen Points (1919). ${ }^{19}$

Hansen's background was particularly suited to the Daily News because he was an expert on contemporary European fiction, was a professional in the public relations side of the job (dealing with book publishers whose advertising made the literary features profitable), and proficient in reviewing books treating the war or its aftereffects. Moreover, he was acceptable to the owner of the newspaper, Victor F. Lawson, who personally commented on Hansen's editorial decisions. ${ }^{20}$

An indication of this reputation appears in a humorous sketch written by George Jean Nathan, prominent New York City drama critic. In this slapstick piece, Nathan suggested the future possibility of a ministry of fine arts as part of the federal government. ${ }^{21}$ Besides accurately predicting a future National Endowment for the Humanities, Nathan had the prescience to include Hansen in the membership list of influential literary people.

\section{III}

In the spring of 1926, Harry Hansen and his family moved to suburban Mount Vernon, New York, near Floyd Dell's house in Croton-on-Hudson. For the next fifty years Hansen lived in Mount Vernon as a suburban commuter to his office in lower Manhattan. He became an "insider" within the publishing world of New York City while serving as literary editor for the New York World. By 1931, his column was syndicated for a national audience of millions.

Hansen quickly adjusted to his new position as literary editor for one of New York City's leading newspapers. While going to his office in the gold-domed Pulitzer Building, Hansen walked through the famous "newspaper row" section of New York. Besides the Pulitzer Building near the Brooklyn Bridge, there were the offices of the Sun where Richard Harding Davis, ace war correspondent, had worked; nearby was the red brick Tribune building where Horace Greeley had written his famous editorials. In the 1920s his friend

19 Hansen's book-length version of the peace conference. The Adventures of the Fourteen Points (1919) received very few reviews.

20 Pencil memo by Victor F. Lawson to Harry Hansen, August 27, 1924. Hansen Papers, Newberry Library. 248.

21 George Jean Nathan. "Clinical Notes," American Mercury 4 (May 1925): 
William McFee worked for the Sun and Burton Rascoe worked for the Tribune before it merged with the New York Herald. Within a few years, he was accepted into a number of prestigious social clubs: the Athletic Club, Player's, Dutch Treat, Larchmont Yacht, and Huguenot Society. He had become a New Yorker.

His national popularity was enhanced by radio broadcasting. From 1931 until 1935, he had the National Broadcasting Corporation's weekly program, "Women's Radio Review." He also appeared as a guest panelist on other network shows. For example, on the evening of September 4, 1938, he appeared on the Columbia Broadcasting System's network show "The People's Platform" with Orson Welles and other panelists.

From 1933 until 1940, Hansen was directly involved in the recognition of writing talent as editor of the O. Henry Memorial Award Prize Stories series. Hansen changed the Prize Stories series to conform with marketing changes and continued criticism. The resulting volumes document the trends and fashions of the decade. In conjunction with the Best Stories series, these volumes provide insight into the theoretical controversies of the decade. In the O. Henry series Hansen continued an emphasis upon commercially acceptable writing.

Harry Hansen became a guide to popular literature for a large audience of newspaper readers. His career in journalism spanned more than three decades before his retirement in the late 1940s. For almost 20 years, Hansen wrote a daily newspaper column that reached a national audience. His interpretations of literary trends and reviews of new books appeared in a column, "The First Reader," syndicated nationally by the Scripps-Howard chain. Throughout his career, Hansen retained his midwestern identity. Norman Cousins, longtime editor of the Saturday Review, recalled him as one of the few writers from Chicago who continued to be an ambassador for that city while living in New York. "Though he never thumped any tubs, his feelings about Chicago were widely known and respected."22 His boyhood on the Mississippi River, experience as a Chicago reporter, and lifelong friendships with other midwesterners provided him with a regional perspective on new books.

Hansen's position as a literary critic on a newspaper meant that he participated in changes in book reviewing. One change was the increased production of new titles each year. In 1884, the year of

22 Letter of Norman Cousins, April 19, 1978, The University of Iowa Libraries. 
his birth, approximately two thousand new books were published each year; this doubled by 1900 to more than four thousand new books and increased to five thousand titles in 1920, eight thousand in 1930, and more than nine thousand in 1940.23

Hansen's productivity in reviewing new books was impressive. For example, in 1927 he wrote a daily column for the New York World, a monthly survey article for Harper's, and book reviews in other periodicals. This yearly output of more than one thousand book reviews covered about 14 percent of the approximately seven thousand new books published. ${ }^{24}$ This represents far more reviewing than other literary journalists normally did, since Hansen was the only New York reviewer writing a daily column.

There were qualitative changes in the American publishing industry after 1918, as new themes were used by writers and experimental forms appeared. For many reviewers, traditional principles of literary criticism failed to apply to many new books. The themes of popular novels changed with the appearance of the working-girl heroine, for example. Russell B. Nye concluded that in this period novels reflected "the facts of a new society, influenced by war, the assembly line, prosperity and depression, permissive psychology, and new kinds of media."25 As popular culture changed, postwar reviewers changed their techniques.

Hansen's productivity was matched by his ingenuity in reviewing the postwar novel. He was regarded throughout this period as a model reviewer. In 1927 Wayne Gard presented him as a leading practitioner of the factual review in his book about literary criticism; in 1936 Florin McDonald treated him as a superb general reviewer in his unpublished study of journalistic reviewers; in 1946 John Drewry described him as "a good example of the objective type of reviewer" in his textbook of book reviewing. ${ }^{26}$ Hansen's reviews were far from pedestrian or ordinary. For example, Hansen reviewed 1919 by John Dos Passos in the form of film clip samples of coming attractions, thereby reproducing the cinematic scene structure found in the novel. ${ }^{27}$

23 Tebbel, A History of Book Publishing, 3: 681.

24 Ibid.

25 The Unembarrassed Muse: The Popular Arts in America (New York: Dial Press, 1970), p. 42.

26 Book Reviewing (New York: Knopf, 1928), p. 49; "Book Reviewing in the American Newspaper" (Ph.D. dissertation, University of Missouri, 1936), p. 38; Writing Book Reviews (New York: Writer, Inc., 1946), p. 7. 27 “1919," New York World-Telegram, March 12, 1932, p. 17. 
Starting in the 1940s, Harry Hansen gracefully moved towards semiretirement. While remaining literary editor for the World-Telegram, Hansen terminated two of his other connections. The 1940 volume of the $\mathrm{O}$. Henry Prize Stories was the last under his editorship. He also ended his association with Harper's, where he had been "book-critic" since August 1923. ${ }^{28}$ Instead of these two secondary assignments, Hansen became a featured columnist for a "light fiction" magazine, writer of a weekly "New York letter" for a Chicago newspaper, and literary editor for one of America's most "liberal" magazines.

Throughout the decade Hansen wrote a short column of monthly "Book Suggestions" for Redbook magazine. This magazine had been established in Chicago in the 1890s as a magazine designed for "the little old ladies in Kokomo." 29 Under the longtime direction of Edwin Balmer, it featured original fiction, condensed novels, and reprinted classics. Hansen's column briefly noted four or more books, compatible with the short stories and serials running in the magazine. ${ }^{30}$

In 1942 Hansen returned to a geographically defined, midwestern audience when he began writing a weekly letter from New York for the new literary supplement to the Chicago Tribune. Generally the column highlighted gossip or trends. In reviewing Bernard DeVoto's The Literary Fallacy, Hansen mentioned the argument contained in the essays, but devoted most of his space to a lively description of the controversy sparked by DeVoto's judgments. ${ }^{31}$

In 1943 Hansen started writing a monthly review article for Survey Graphic, a magazine presenting professional articles for the social worker. In this decade the magazine had become synonymous with supporters of Franklin D. Roosevelt's New Deal. Hansen's monthly contribution was the "leader" or major review essay for the bookreview section. His essay was longer than his newspaper column, usually highlighting one or two books each month. For five years Hansen was associated with this magazine, which became famous for a series of symposium issues, "Calling America." 32

After 50 years in journalism, Hansen ostensibly retired on October 30,1948 . Although leaving the daily routine of journalism, he only

28 "Announcement," Harper's 178, no. 1 (December 1938): 113. 211.

29 John Tebbel. The American Magazine (New York: Hawthorn, 1969), p.

30 Harry Hansen, “Book Suggestions for July," Redbook (July 1940).

31 "War Flares Up on Literary Front over DeVoto's Book," Chicago Tribune, April 23, 1944, p. 15.

32 Frank Luther Mott, A History of American Magazines, vol. 4. 
moved up the block to another office, inasmuch as he became general editor of the World Almanac. ${ }^{33}$ When the Scripps-Howard media corporation was negotiating to buy the World, Hansen had met with Roy W. Howard about the rights to publish the almanac. ${ }^{34}$ Apparently the corporation executives remembered him when the previous editor died. Hansen replaced E. "Deac" Eastman Irvine, originally from Cresco, Iowa. ${ }^{35}$ For the next 17 years Hansen occupied this comfortable vantage point. Each year he wrote a review of noteworthy events and expanded the scope of the almanac, which remained a standard reference source during his tenure. ${ }^{36}$ His former boss at the World, Herbert Swope, caught an uncharacteristic error in the impossible title for a section on card games, "5 Suit Poker Hands," in the 1951 edition. ${ }^{37}$

In 1965 Hansen retired from the editorship of the almanac and became a senior editor for Hastings House. This small publishing firm was perfect for his purposes. In his eighties, Hansen assumed editorial control over the revised American Guide series of state histories. His method was to update the Works Progress Administration guides of the 1930s, adding contemporary illustrations and revising the statistics.

Hansen was working on the galley proofs of a New Jersey guidebook in December 1976 when he was stricken with a heart attack. His death a month later ended a unique career. Although his fame was based largely upon his syndicated newspaper column, his 30 year semiretirement period was remarkable not only for the number of projects he completed, but also for the financial security he attained. Unlike many of his contemporaries, Hansen remained in comfortable surroundings. It was a strategic retreat from an audience of millions who have forgotten him.

33 "Harry Hansen Becomes Editor of World Almanac," Publisher's Weekly 154, no. 19 (November 6, 1948).

34 Letter of Lee B. Wood, May 3, 1978, The University of Iowa Libraries.

35 "Eastman Irvine," New York Times, September 24, 1948, p. 25.

36 Harry Hansen, "What the Year's Big Events Mean," World Almanac (New York: 1960 ).

37 Quoted by Ely J. Kahn. The World of Swope (New York: Simon \& Schuster, 1965), p. 70. 


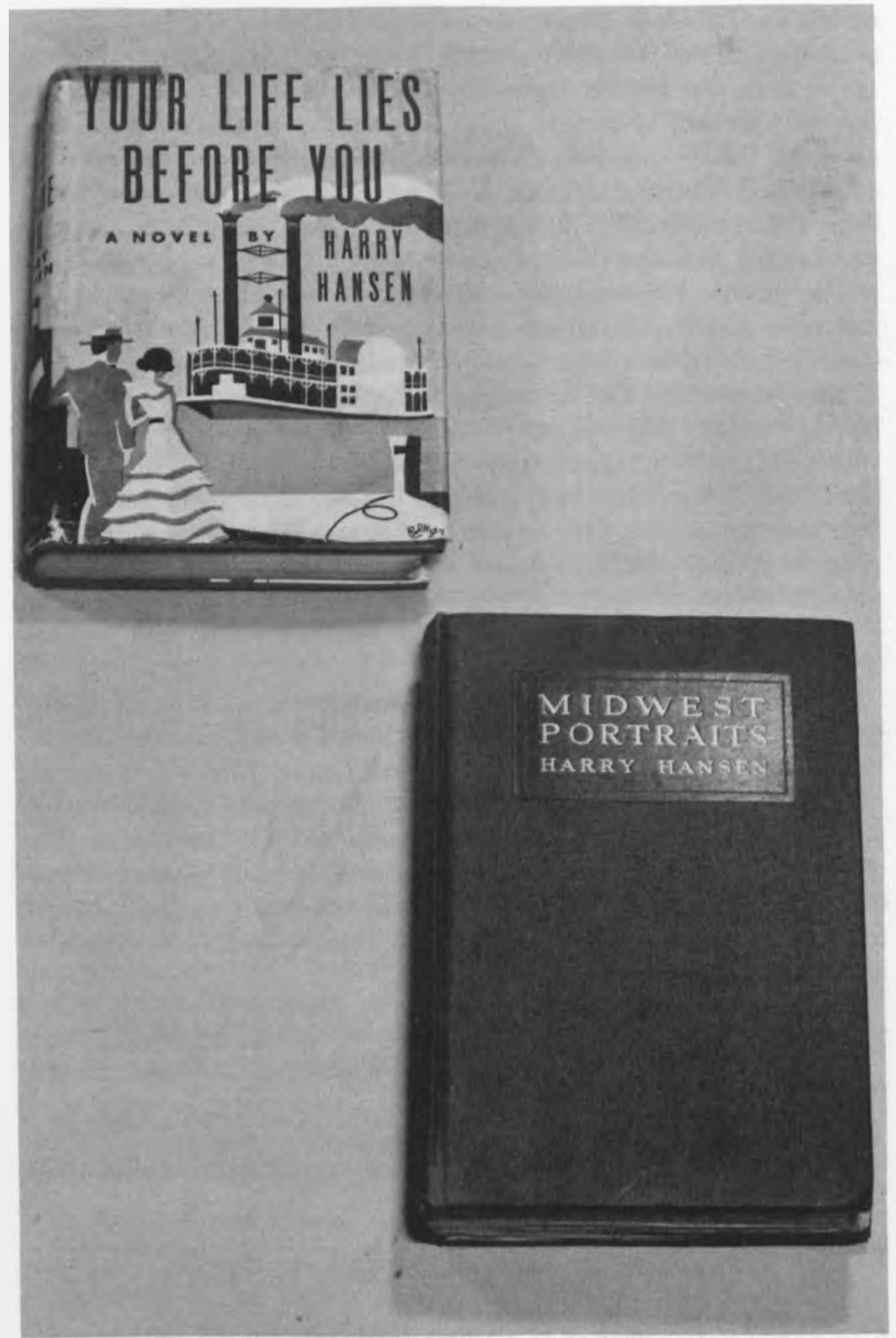

A novel by Harry Hansen, published in 1935, and a book about some of his midwestern literary associates, dating from 1923. From the Iowa Authors Collection. 


\section{Harry Hansen: A Selective Checklist}

The citations in the following brief checklist of Harry Hansen's voluminous writings have been selected from several hundred entries recorded in William Roba's unpublished doctoral dissertation “A Literary Pilgrim: Harry Hansen and Popular American Book Reviewing, 1915-1945" (The University of Iowa, 1979), pp. 175-266. They have been chosen as more or less accessible items which indicate the range and diversity of Hansen's publications.

\section{9}

"The Last Cruise of the Buena Vista," Red and Blue 2, no. 1 (September 1899): 6-7.

"Told in the Twilight," Red and Blue 2, nos. 2-4 (October-December 1899): 7-8, 5-7, 7-8.

\section{9-1911}

Unsigned Book Reviews, University of Chicago Magazine 1-3.

"Home-coming of Chicago Men," University of Chicago Magazine 3, no. 6 (July 1911): 303-11.

\section{5}

"Brussels und Umbebung," University of Chicago Magazine 8, no. 2 (December 1915): 61-65.

1916

"What Happened in Beaumont," University of Chicago Magazine 8, no. 5 (March 1916): 201-7.

1918

"Introduction," A Peace Congress of Intrigue by Frederick Freksa, New York: Century, 1918.

1919

The Adventures of the Fourteen Points. New York: Century, 1919.

1923

Midwest Portraits; A Book of Memories and Friendships. New York: Harcourt, Brace and Company, 1923.

1924

"Harry Hansen, Reviewer of Books. By Himself," Nation 118, no. 23 (June 4, 1924): 646-47.

Carl Sandburg, The Man and His Poetry. Girard, Kansas: HaldemanJulius Company, 1925. 
"Some Meditations on the Radio," Nation 120, no. 11 (March 25, 1925): 324-25.

1926

"From Chicago to New York," Bookman 69, no. 4 (December 1926): 453.

1930

"Those Literary Lobbies," North American Review 230, no. 2 (August 1930): 162-68.

"War on the Book Front," Outlook 155, no. 24 (June 11, 1930): 220-21.

1931

"Iowa Writers' Conference," Saturday Review of Literature 8, no. 18 (November 21,1931 ) : 315 .

"The Last Reader," The End of the World; A Post Mortem, edited by James W. Barrett. New York: Harper, 1931.

1932

“On Memorizing," School Life 17, no. 9 (April 1932): 150.

1933

"Fashions in Fiction," Forum 89, no. 3 (March 1933): 152-55.

"Librarians Capture the Depression," Survey Graphic 22, no. 12 (December 1933): 634-35.

1934

"Hansen Traces Growth of Reviews," Publisher's Weekly 126, no. 8 (July 28, 1934): 281.

"Book Reviews Resist Commercialism," Editor and Publisher 67, no. 10 (July 21, 1934): 105, 128.

1935

Your Life Lies Before You. New York: Harcourt, Brace and Company, 1935.

1939

"Literary Previews," Writing Up the News; Behind the Scenes of the Great Newspapers, edited by Miriam Lundy. New York: Dodd, 1939.

"Brothers Grimm," Horn Book 15, no. 2 (March-April 1939): 113-20.

1941

“Anderson in Chicago," Story 25, no. 8 (September-October 1941): 34-36.

1942

"Sherwood Anderson's Story," Saturday Review of Literature 25, no. 15 (April 1, 1942): 5-6.

The Chicago. New York: Farrar and Rinehart, 1942. 


\section{6}

"How to Give Away an Opera House," Journal of the Illinois State Historical Society 39, no. 4 (December 1946): 419-24.

\section{7}

“Chicago," Holiday 2, no. 2 (May 1947): 18-27, 54-59, 61-63.

1948

"Dilemma of Modern Writing," Survey Graphic 37, no. 1 (January 1948): 30-31.

$$
1950
$$

North of Manhattan; Persoms and Places of Old Westchester. New York: Hastings House, 1950.

Scarsdale, From Colonial Mansion to Modern Community. New York: Harper, 1954.

“A Davenport Boyhood," Palimpsest 37, no. 4 (April 1956): 161-224.

\section{1}

The Civil War; A New One-Volume History. New York: New American Library, 1961.

1970

The Boston Massacre: An Episode of Dissent and Violence. New York: Hastings House, 1970. 